\title{
Assessing bioenergy potential in rural areas - A NEG-EROEI approach
}

\author{
Oludunsin Arodudu ${ }^{a, *}$, Alexey Voinov ${ }^{b}$, Iris van Duren ${ }^{b}$ \\ ${ }^{a}$ Leibniz-Centre for Agricultural Landscape Research (ZALF), Eberswalder Straße 84, 15374 Müncheberg, Germany \\ b ITC, University of Twente, Hengelosestraat 99, Enschede, Netherlands
}

\section{A R T I C L E I N F O}

\section{Article history:}

Received 8 January 2013

Received in revised form

20 July 2013

Accepted 28 July 2013

Available online 23 October 2013

\section{Keywords:}

EROEI

NEG

GIS

LCI

Crop residue

Manure

\begin{abstract}
A B S T R A C T
Most sources of biomass are located in rural areas, and use of this biomass for bioenergy may be in conflict with agricultural and conservation purposes. This study applied Life Cycle Inventory (LCI) and Geographical Information System (GIS) tools to estimate the Net Energy Gain (NEG) and Energy Return on Energy Invested (EROEI) for different biomass/ bioenergy production activities in rural areas. The focus was on those activities that are least damaging or even socially, environmentally or economically beneficial. We considered bioenergy production from crop residues, manure, and grass in natural grasslands and surplus pasturelands. The feasibility and vulnerability of different sources was assessed within the context of existing policy constraints, and the potential contribution to the EU's bioenergy targets was evaluated. Taking the Overijssel province in the Netherlands as a case study, we showed that $66.01 \mathrm{PJ}$ can be contributed from by-products, with an additional $3.34 \mathrm{TJ}$ coming from more conventional pasturelands. The NEG from biogas can potentially take care of Overijssel's entire renewable energy target for the year 2030. When producing bioenergy from by-products, the EROEI is quite high (7-17), indicating that there is a big potential for by-products to provide energy without compromising the ecological or agricultural functions of the landscapes. However there are still many changes in the practices, technologies and policies associated with bioenergy production that have to be made to harvest this potential energy resource.
\end{abstract}

() 2013 Elsevier Ltd. All rights reserved.

\section{Introduction}

The search for renewable energy sources has become more intense, because global fossil fuel reserves are depleted while climate change puts additional restrictions on using even what is still left [1,2]. The reduction of global fossil fuel consumption and the adoption of cleaner renewable energies as a way of slowing down global warming rates are receiving great attention amongst policy makers and stakeholders globally [3].
Under the Kyoto Protocol obligation, the EU pledged a minimum target of $20 \%$ of total energy consumption to be provided from renewable sources and $10 \%$ of total transport fuel mix to be covered from renewable sources by the year 2020 [4]. Netherlands national share of energy from renewable sources was only $2.4 \%$ in 2005 and $4 \%$ in 2010 . Based on this development, the Netherlands Government has set a new minimum target of $14 \%$ (2.1 EJ) by the year $2020 ; 54.5 \%$ of which is expected to be from biomass sources (0.30 EJ) [5], but

\footnotetext{
* Corresponding author. Tel.: +49 15217591767.

E-mail addresses: oludunsinarodudu@gmail.com, Oludunsin.Arodudu@zalf.de (O. Arodudu), voinov@itc.nl (A. Voinov), vanduren@ itc.nl (I. van Duren). 
analyses of where and how this energy is going to be produced are quite scarce [6,7].

Conventional biomass production for bioenergy is often associated with the availability of land for cultivation of bioenergy crops [8]. 19 million hectares of surplus pasturelands can be economically available and freed up for bioenergy production within Europe (Ukraine inclusive) by the year 2030, but this land is unevenly distributed [6]. Some EU countries like the Netherlands are highly urbanized with welldeveloped infrastructures and services that can support massive bioenergy production. However, the intensive use of its limited land resources makes meeting local biomass demand for bioenergy production difficult [9]. Using available arable land for the production of bioenergy crops can affect the local food production chain [10]. Increasing agricultural land use at the expense of reserved or conserved land will impact environmental quality, biodiversity and other socioecological considerations [11]. Consequently, the bioenergy potential of biomass sources other than cultivation of excess or conserved land becomes especially attractive. Examples of these potential flows include animal waste, domestic and industrial human waste, urban lands (roadside vegetation, rooftop crops etc.), algae etc.

Of great importance for bioenergy production is its sustainability. This can be evaluated in terms of multiple policy constraints such as food security, nature conservation needs, water footprint, socio-economic needs and the well-being of the local people involved [10-14]. Any biomass production activity considered as sustainable must not compete with any food production, distribution or use chains e.g. the use of land devoted to food production for bioenergy production should be prohibited. Biomass production activity for bioenergy production must not be in conflict with any nature conservation and social land use functions e.g. soil and water conservation, ecosystem and habitat preservation, plant and animal biodiversity, means of income and livelihood, land ownership and housing rights, rights to space for recreation etc. $[6,10,14,15]$. At the same time, we need to make sure that the production is energy efficient, meaning that we are not using more energy in the production chain than what we are gaining as output.

\section{Assessment of the bioenergy potential}

Previous bioenergy potential assessments often consider how much land is available, the potential biomass yield, the potential energy output and the money to be invested and gained as measures of bioenergy potentials [9,16-20]. Available land as a measure of bioenergy potential only considers land related factors; e.g. the area that can be sustainably used for biomass/bioenergy production, the most suitable bioenergy crop under prevailing local conditions e.g. climate, soil and socio-economic factors etc. [19]. Assessing bioenergy potentials in terms of biomass yield per hectare is only applicable to biomass that grows on land and is therefore quantifiable by area (hectares) of land. Other biomass sources are quantified differently because they are point sources and not products of direct biomass growth on land. Examples include products of human activities such as farm manure, refuse, garden wastes, industrial wastes etc. [18]. The use of available land, the potential biomass yield per hectare and the potential energy output also does not account for energy invested to obtain the energy output. Besides, measuring the bioenergy potential in monetary terms is inaccurate because prices fluctuate and are susceptible to lots of political and market mechanisms such as subsidies or taxes $[9,16,20]$.

Assessing bioenergy potentials using energy-based indices integrates spatially distributed, land-grown and point biomass sources, potential energy outputs, energy investments into obtaining the output, and the energy gained from various biomass/bioenergy production activities. We focused on two of such energy-based indices as measures of bioenergy potential. They are the Net Energy Gain (NEG) and the Energy Return on Energy Invested (EROEI) indices. NEG is the gained difference in energy between energy invested into a biomass/bioenergy production activity and the energy output returned after production [21].

Net Energy Gain (NEG) = energy output - energy input

Net Energy Gain becomes a loss when it is less than 0 .

EROEI (energy efficiency) is the ratio of the energy output (expected return) obtained from a particular biomass/bioenergy production activity to the energy input (investment) required to get that energy [22].

EROEI $=$ expected energy output/required energy investment

NEG estimates the amount of energy that will be gained from the biomass/bioenergy production [21]. EROEI is a measure of efficiency, and as such indirectly estimates the ability of the energy production activities to be sustainable. Energy production with an EROEI value greater than 3 is considered capable of supporting continuous socio-economic function while those below 3 are not [22]. This is because at low efficiencies other externalities that are hard to quantify in purely energy terms (such land degradation, water pollution, biodiversity impacts, etc.) become more pronounced and make the sustainability of the production system questionable. In line with ex-ante land use impact assessment trends aimed at ensuring sustainability, an assessment of rural bioenergy potential will be incomplete without assessing its impact across the three sustainability dimensions (environment, society and economy) with a view to achieve considerable balance through stakeholder engagement $[23,24]$.

\section{Methodology}

This study seeks to develop a balanced approach for assessment of bioenergy potential using the NEG-EROEI metrics. We did this by selecting a suitable case study area, biomass options and technology; computing the energy inputs and outputs using a combination of LCI analysis and GIS operations; calculating and comparing the NEG and EROEI of different rural biomass sources; and holding consultations with relevant stakeholders with a view to assess the environmental, socio-economic, technological and policy impacts associated with exploiting bioenergy potentials in rural areas. This is illustrated in Fig. 1. 


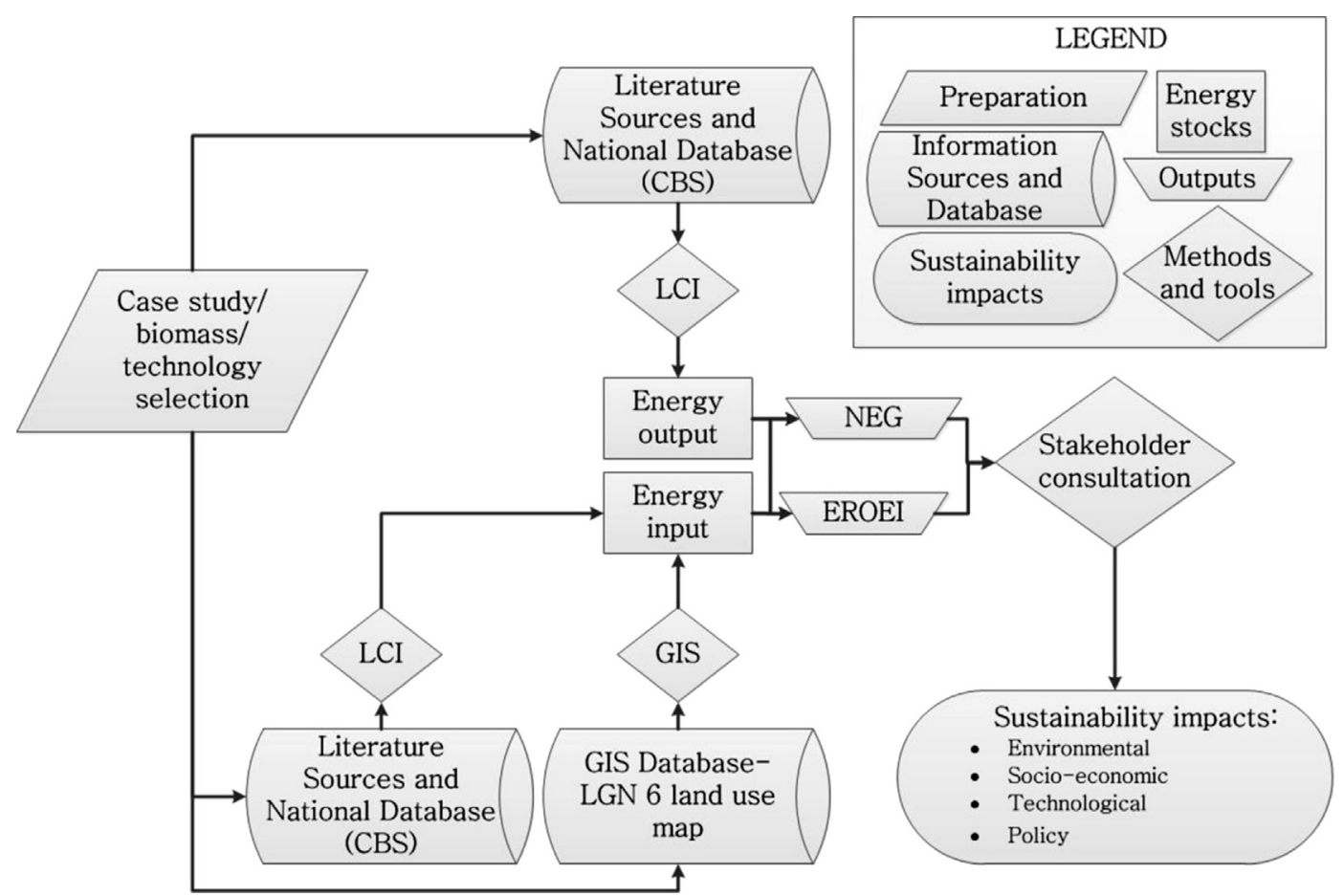

Fig. 1 - Methodological framework.

\subsection{Case study area selection: Overijssel province}

This study focused on the Dutch province of Overijssel (Fig. 2). Overijssel has a mix of land cover quite close to that of the whole Netherlands (build-up - 10\% in Overijssel vs. 14\% in NL, agriculture $-79.8 \%$ vs. $74.3 \%$, and forest $-10.2 \%$ vs. $12.1 \%$ ) [25]. This allows us to extrapolate some of our results and conclusions over the whole of the Netherlands.

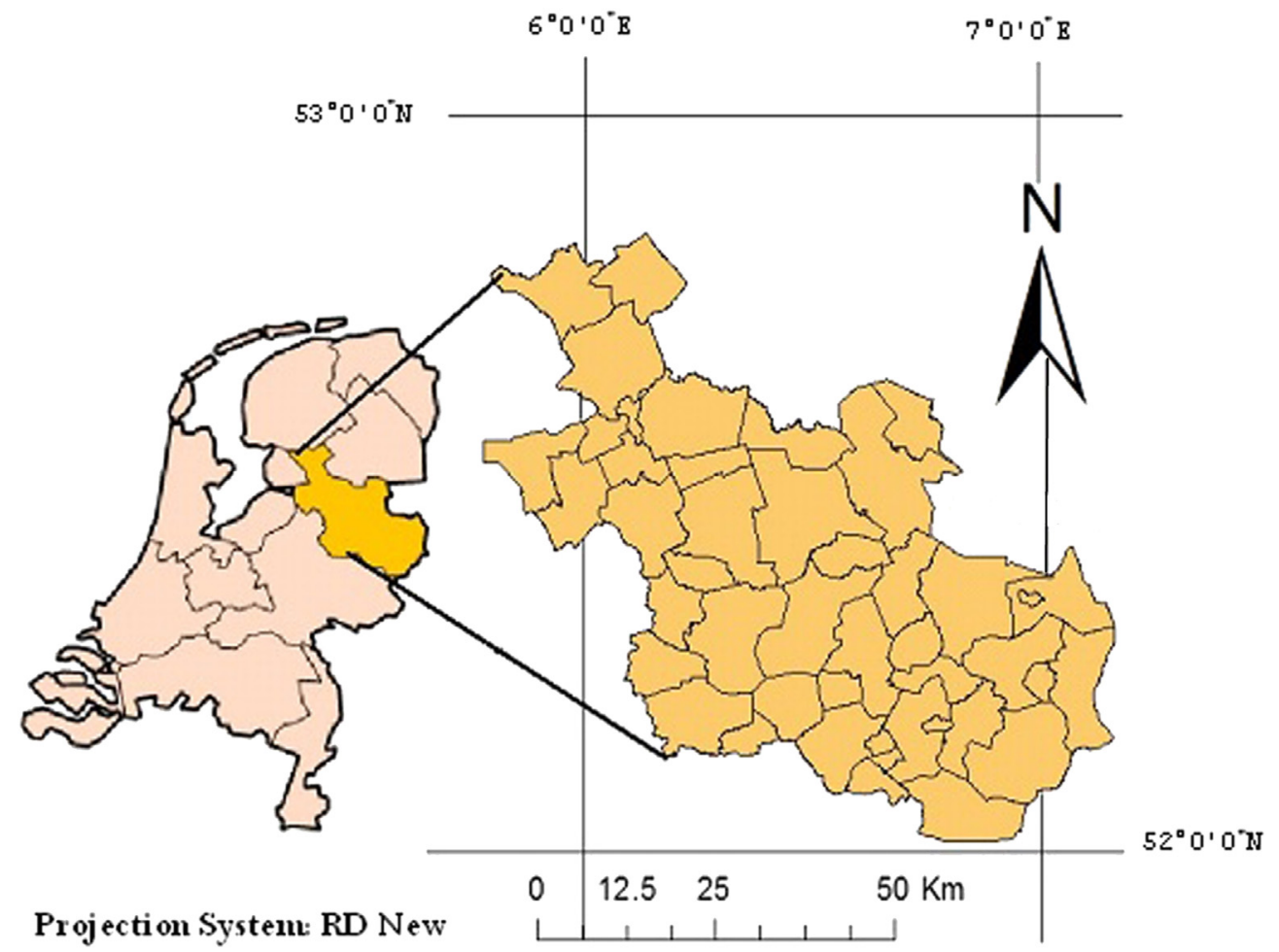

Fig. 2 - Location and the municipality boundaries of the study area (Overijssel province) as part of the Netherlands (Source: Top 10 Vector files). 
The projected bioenergy target for Overijssel by 2030 as extrapolated from the breakdown of the national renewable targets by PGG (Platform Groene Grondstoffen) is as follows: about $23 \mathrm{PJ} \mathrm{y}^{-1}$ of transport fuels, $13 \mathrm{PJ} \mathrm{y}^{-1}$ of heat, $14 \mathrm{PJ} \mathrm{y}^{-1}$ of electricity and $10 \mathrm{PJ}^{-1}$ of industrial raw materials (totalling about $60 \mathrm{PJ} \mathrm{y}^{-1}$ ) $[26,27]$.

\subsection{Selection of biomass/bioenergy production activities in rural areas}

The biomass/bioenergy production activities examined by this study are limited to four options in the rural areas namely: growing feedstock; utilizing crop residues; collecting farm manure and using grasses from natural grasslands. These sources where considered at least benign and even beneficial in terms of sustainability concerns such as food security, nature conservation and socio-economic functions.
A brief analysis of these options with respect to the different sustainability concerns is given in Table 1 .

Crop residues, farm manure and left over grass decompose, potentially creating nuisance to people (odours), and releasing innate $\mathrm{CO}_{2}$ back to the atmosphere [39]. However, if they are used as biomass for bioenergy production, the carbon in the waste can be captured and converted into usable and carbon-neutral energy [17,30]. As a result, instead of spending additional energy and resources to treat the waste; farmers and grassland managers gain access to potential extra income and employment opportunities [10].

\subsection{Selection of technology}

There are different technologies available for conversion of biomass into energy; but we focused on wet anaerobic codigestion because of the proximity to and contiguity of the

\section{Table 1 - Brief analysis of biomass/bioenergy production options in rural areas.}

Biomass/bioenergy production options

\section{Growing feedstock e.g. alfalfa on surplus pasturelands}

Utilizing crop residues (straw)

Collecting farm manure

Using grasses from natural grasslands
Evaluation (benignity and benefits) in terms of relevant sustainability constraints (food security, nature conservation, socio-economic functions)

Occasioned by advent of high-performance diets and consequent reduction in importance of grass as animal feed [8,15]; not in conflict with present and future fodder needs (meets future forage needs) [6]; maintains soil structure and nitrogen nutrient status [14]; extra source of income and employment for farmers; does not trample with ownership rights of local people. However, changing agricultural demands and policies makes sustainability in the long run doubtful. Also the sustainability of high-performance diets is dubious [8]. Three possible harvest schemes on pasturelands in the Netherlands: early harvest scheme (grass is harvested when less than $12 \mathrm{~cm}$ in height), results in lower yield per harvest $\left(2 \mathrm{tha}^{-1}\right.$ ) but allows for more regrowth and harvest opportunities (3 harvest annually); late harvest scheme(grass is harvested when more than $25 \mathrm{~cm}$ in height), results in higher yield ( $5 \mathrm{tha}^{-1}$ ) but less opportunity for fast regrowth and therefore less number of harvests (just 1 harvest annually); intermediate harvest scheme- (grass is harvested when between 15 and $20 \mathrm{~cm}$ in height), results in relatively high yield (up to $4 \mathrm{t} \mathrm{ha}^{-1}$ ) and allows for one more regrowth and harvest opportunity (2 harvest annually) [28].

Residues from high residue yielding commercial (annual) crops is often burnt off, composted or left to oxidize or decompose; can be recaptured by little modification of existing production chain, use of appropriate technology, creation of incentives and efficient collection methods [29]. Excess available within EU after use as compost for nutrient replacement, substrate for mushroom production, animal beddings, insulating materials for building and to a lesser extent in paper and pulp industries (e.g. for maize and rapeseed - 50\%; for wheat, oat, barley and tritacle - 40\%) [30]. Does not compete with food production, distribution and use chains. Digestates from bioenergy production can be used to replenish nutrients in soils hereby making composting irrelevant. EU Nitrates Policy and EU Water Framework Directive prohibits direct and unrestricted use of farm manure for soil conservation and food production (to prevent over enrichment of soils, nearby surface and ground water) [31]. Manure is expected to be refined, recovered and applied to farmlands in required quantities after mineral accounting had been done and nutrient deficiency identified. This policy favours the use of farm manure for bioenergy production because resulting digestate can be used as fertilizer; digestate is easier to handle than raw manure, it protects the environment from the risk of over-enrichment and consequent eutrophication; offers a sustainable pathway for handling farm odours and air pollution; reduces or totally eliminates energy and economic costs of fertilizer production; makes possible the export, redistribution and recycling of excess farm manure [32]. Of special interest is dairy and beef cattle, chicken and pig because of their high population, high manure yield (dairy and beef cattle) and high energy yield (pigs and chicken) [33-35].

Natural grassland management policy of the Netherlands requires that grasslands be mown two or three times annually for nature conservation purposes (reduction of nutrients in the ecosystem and restoration of ecological diversity) [36,37]. About $50 \%$ of silage grass from natural grasslands is usually used to supplement the grass in the feed-mix; however $50 \%$ of that can be made available for bioenergy production [38]. Natural grasslands are not commercially owned and therefore do not affect the rights, employment status and sources of income of the local people. The three possible harvest schemes on pasturelands in the Netherlands were also assumed for natural grasslands [28]. 
different biomass sources, and the convenience of processing them together, e.g. grass, manure, straw etc. [40]. This technology spends no energy on drying of biomass, produces higher biogas yield and better mixed digestate (with more balanced NPK ratio) than in case of mono-digestion; it can be situated centrally around agricultural or industrial or domestic biomass sources or on farm sites (farm-scale) [32,41]. The products of wet anaerobic co-digestion of grass, manure and crop residue (straw) are biogas and digestate (by-products) [42]. Biogas can be used for producing transport fuels and in fuel cells, generating heat in boilers, producing heat and electricity together via Combined Heat and Power (CHP) technology. Digestates can be used as replacements for fertilizers or for mineral recovery, e.g. phosphate from pig manure [32,42]. This immediately brings us to prioritizing production from by-products and waste materials. Still a careful analysis of energy inputs and outputs, as well as the uncertainties associated with the production chain is required.

\subsection{Life Cycle Inventory (LCI)}

An LCI for a biomass source involves a listing of all the elements of biomass and energy production in terms of energy input and the potential energy output obtainable from various sources [43]. While estimating the energy inputs and outputs of the various biomass sources, an LCI for a biomass source also takes into consideration the various biomass/bioenergy conversion models and coefficients involved in the estimation. The LCI was done by drawing instances from literature [40,44-49]. However, some biomass/bioenergy conversion models and coefficients were not explicitly found. In such cases we made assumptions based on similar processes or production chains. The biomass source-specific inputs are presented in Table 2 .

On arrival at the digester, all biomass types require energy for oxidation process and energy for biogas plant operations [50]. Also, all through the production chain throughout the year, energy for human labour is also needed. Expected energy outputs on the other hand include [33-35,41,46,48,51]:

1. Energy from biogas

2. Energy from digestate-fibre (N-nitrogen, P-phosphorus, $\mathrm{K}$-potassium)
3. Energy from digestate-liquor (N-nitrogen, $\mathrm{P}$-phosphorus, $\mathrm{K}$ potassium)

Energy inputs in form of fuel (diesel and/or gasoline) used by tractors, trucks and farm machinery for field operations, or in form of natural gas (LPG) or electricity consumed for postfield operations, pre-treatment and processing were all converted into the SI unit for energy (Joules) for data harmonization. $1 \mathrm{~L}$ of gasoline fuel is equivalent to $32 \mathrm{MJ} ; 1 \mathrm{~L}$ of diesel fuel is equivalent to $36.4 \mathrm{MJ}$; $1 \mathrm{~L}$ of LPG natural gas is equivalent to $34.6 \mathrm{MJ}$ while $1 \mathrm{kWh}$ of electricity is equivalent to $3.6 \mathrm{MJ}$ [44]. Biogas contains $21.6 \mathrm{MJ} \mathrm{m}^{-3}$ ( $\mathrm{HHV}$ at standard temperature and pressure of $273 \mathrm{~K}$ and $100 \mathrm{kPa}$ ). The energy from digestate is assumed to be equivalent to the energy for the production of the fertilizer that replaces it [46]. The energy for the collection, storage and haulage of chicken manure was based on the assumption that a chicken uses $1 / 25$ th of the area a cow uses [52]. The energy for human labour was based on the assumption that in bioenergy production per day it does not exceed the upper limit of human energy consumption for timber harvesting for a day [53]. All these coefficients and conversion factors where assembled in a spreadsheet and provided as Supplementary information to this paper [54].

\subsection{Calculation of NEG and EROEI}

To determine the NEG and EROEI of bioenergy production, we estimated two energy flows: the potential energy invested into obtaining energy from various sources, and the potential energy output (yield) obtainable from them. As illustrated in Fig. 1, this study used a combination of Life Cycle Inventory (LCI) and GIS for the compilation of all the energy inputs and outputs involved in the production of energy from biomass sources in Overijssel province. Information on the biomass and energy conversion factors where obtained from literature sources $[6,28,30,38,40,48,55]$. This includes average grass yield of natural grassland and surplus pasturelands and their relative availability for bioenergy production; the range of crop residue yield and their relative availability for bioenergy production; the average annual manure yield per animal and their relative availability for bioenergy production; energy input conversion coefficients, average biogas and energy yield per substrate type. The range of biomass yield, biogas yield, energy input and outputs were estimated using the

\begin{tabular}{|c|c|c|c|c|c|c|}
\hline $\begin{array}{l}\text { Biomass/bioenergy } \\
\text { production options }\end{array}$ & Energy input 1 & Energy input 2 & Energy input 3 & Energy input 4 & Energy input 5 & Energy input 6 \\
\hline Crop residues (straw) & $\begin{array}{l}\text { Mowing and } \\
\text { chopping residues }\end{array}$ & Stalk shredding & Baling and stacking & $\begin{array}{l}\text { Transportation } \\
\text { to digester }\end{array}$ & - & - \\
\hline Farm manure & $\begin{array}{l}\text { Collection, storage } \\
\text { and haulage }\end{array}$ & $\begin{array}{l}\text { Transportation } \\
\text { to digester }\end{array}$ & - & - & - & - \\
\hline $\begin{array}{l}\text { Grasses from natural } \\
\text { grasslands }\end{array}$ & $\begin{array}{l}\text { Mowing and } \\
\text { chopping }\end{array}$ & $\begin{array}{l}\text { Baling and } \\
\text { stacking }\end{array}$ & $\begin{array}{l}\text { Transportation } \\
\text { to digester }\end{array}$ & - & - & - \\
\hline $\begin{array}{l}\text { Grasses (alfalfa) from } \\
\text { surplus } \\
\text { pasturelands }\end{array}$ & $\begin{array}{l}\text { Cultivation } \\
\text { of land }\end{array}$ & $\begin{array}{l}\text { Fertilizer } \\
\text { application } \\
(\mathrm{N}, \mathrm{P}, \mathrm{K})\end{array}$ & $\begin{array}{l}\text { Crop protection } \\
\text { (insecticides, } \\
\text { herbicides, pesticides) }\end{array}$ & $\begin{array}{l}\text { Mowing and } \\
\text { chopping }\end{array}$ & $\begin{array}{l}\text { Baling and } \\
\text { stacking }\end{array}$ & $\begin{array}{l}\text { Transportation } \\
\text { to digester }\end{array}$ \\
\hline
\end{tabular}


conversion factors and annual data on crop yield, animal population and area covered by surplus pasturelands for three years (2009-2011) obtained from the CBS (Central Bureau of Statistics, Den Haag, Netherlands). However, areas covered by natural grassland were not available in the CBS database; they were therefore extracted from a Land use map (LGN - Landelijk Grondgebruiksbestand Nederland 6 land cover map) obtained from the LGN Dutch Land use database, Wageningen University and Research Centre, Netherlands.

\subsection{Calculation of natural grassland area}

All GIS operations were performed in ArcGIS version 10.0. The area covered by natural grasslands was extracted from the LGN 6 land cover map. It is in raster format with a resolution of $25 \times 25 \mathrm{~m}$ and has 39 land cover classes. The following GIS based procedures were followed to obtain the areal coverage (in $\mathrm{km}^{2}$ ) of natural grasslands within the Overijssel province: We converted the raster based LGN 6 land cover map into a polygon mapped and clipped it to the extent of the province Overijssel. Then, we recalculated the areal geometry, selected natural grassland areas and extracted the area sizes for all natural grasslands.

The accuracy of the LGN 6 land cover classification was 80-90\%. Therefore we applied an error margin of $\pm 20 \%$ (worst case scenario) in subsequent calculations of potential biomass yield and availability for bioenergy production, energy inputs, outputs, NEG and EROEI of grasses from natural grasslands. The grass yields were assumed to be the same for all the grassland and pastureland areas [28].

\subsection{Stakeholder consultation}

To assess the sustainability impacts of exploiting rural bioenergy potentials, this study initiated a preliminary dialogue with stakeholders in the bioenergy sector. The consultation process was however limited to practitioners in the frame of the BE2.O (Bioenergy for Overijssel) project (a forum of technologists and bioenergy researchers). Participating stakeholders freely shared their experiences, preferences, bias, doubts and misgivings on the sustainability impacts of exploiting rural bioenergy potentials in a most objective way using local and expert scientific knowledge and facts [54]. The findings were quite robust and broad-based, cutting across relevant sustainability themes including environmental, socio-economic, technological and policy impacts.

\section{Results \\ 4.1. Biomass yield and biomass available for bioenergy production}

In Table 3, we present our estimates for the amounts of biomass in natural grasslands and surplus pasturelands that can be made available for energy production. We see that the intermediate grass harvest scheme produces more biomass than the other grass harvest schemes, and provides more room for maximizing potential grass yield from the same size of land. Like for the grasses cultivated on surplus pasturelands, the intermediate harvest scheme produced the highest biomass yield on the natural grassland.

In Table 4, we show the estimates for biomass of crop residues and manure in the province. Although maize has a low crop to residue ratio, due to the vast maize quantities produced the amount of maize residue is high in comparison with other crop residues [30]. The dairy cattle makes more biomass available for bioenergy production than beef cattle because of the continual optimization of indoor management systems to get more milk from them [55].

\subsection{Energy input, energy output, NEG and EROEI}

Next we take the coefficients resulting from the LCI and apply them to the total amounts of different types of biomass available in the province. Tables 5 and 6 presents the various amounts of energy associated with biomass from surplus pasturelands and natural grasslands respectively. Planting alfalfa grass was found to be less energy efficient than mowing of grasses from natural grasslands for bioenergy production. Of all the rural biomass sources considered by this study, grasses from natural grasslands have the highest net energy gain per tonne of biomass ( $9 \mathrm{GJ} \mathrm{t}^{-1}$ of biomass).

From Table 5, we can see that the late harvest scheme is the most energy efficient and feasible harvest scheme for planting of bioenergy crop (alfalfa) on surplus pasturelands. The energy efficiency of the early harvest scheme is lower. Much energy is invested into cultivation, fertilizers and crop

Table 3 - Biomass yield and biomass available for bioenergy production in tonnes (grasses from surplus pasturelands and natural grasslands).

\begin{tabular}{lccc}
$\begin{array}{l}\text { Grass harvest scheme } \\
\text { (natural grassland) [28] }\end{array}$ & $\begin{array}{c}\text { Potential total biomass } \\
( \pm 20 \% \text { accuracy) }(t)\end{array}$ & $\begin{array}{c}\text { Percentage availability } \\
\text { of total biomass [38] }\end{array}$ & $\begin{array}{c}\text { Biomass available } \\
\text { for bioenergy production (t) }\end{array}$ \\
\hline Early & $34,356.9-57,261.5$ & $50.0 \%$ \\
Intermediate & $45,809.2-76,348.7$ & $50.0 \%$ & $17,178.5-28,630.8$ \\
Late & $28,630.8-47,717.9$ & $14,315.4-23,858.0$ \\
\hline Grass harvest scheme & Range of potential total & Percentage availability & Biomass available for bioenergy \\
(surplus pasturelands) [28] & biomass (2009-2011) (t) & of total biomass [6] & 174.4 \\
Early & $453.2-747.3$ & $100.0 \%$ & $100.0 \%$ \\
Intermediate & $604.3-996.4$ & $353.2-747.3$ \\
Late & $377.7-622.8$ & $304.3-996.4$ \\
\hline
\end{tabular}


Table 4 - Biomass yield and biomass available for bioenergy production in tonnes (crop residues and farm manure).

\begin{tabular}{|c|c|c|c|c|c|}
\hline Crop type & $\begin{array}{c}\text { Annual range of crop yield } \\
\text { (Central Bureau of Statistics-CBS } \\
\text { 2009-2011 for Overijssel province) (t) }\end{array}$ & $\begin{array}{l}\text { Crop to } \\
\text { residue } \\
\text { yield ratio }\end{array}$ & $\begin{array}{l}\text { Potential biomass } \\
\text { yield } \\
(2009-2011)(t)\end{array}$ & $\begin{array}{l}\% \text { Available for } \\
\text { bioenergy } \\
\text { production [30] }\end{array}$ & $\begin{array}{l}\text { Potential biomass } \\
\text { available for } \\
\text { bioenergy production } \\
(2009-2011)(t)\end{array}$ \\
\hline Corn & $1,868,988.0-2,017,675.0$ & $0.7-1.2$ & $1,308,291.6-2,421,210.0$ & $50.0 \%$ & $654,145.8-1,210,605.0$ \\
\hline Rye & $1542.0-2363.0$ & $1.7-1.75$ & $2621.4-4135.3$ & $40.0 \%$ & $1048.6-1654.1$ \\
\hline Triticale & $2467.0-3822.0$ & $0.6-1.8$ & $1480.2-6879.6$ & $40.0 \%$ & $592.1-2751.8$ \\
\hline Wheat & $14,057.0-17,925.0$ & $0.6-1.8$ & $8434.2-32,265.0$ & $40.0 \%$ & $3373.7-12,906.0$ \\
\hline Oat & $392.0-413.0$ & $1.0-2.0$ & $413.0-826.0$ & $40.0 \%$ & $94.8-330.4$ \\
\hline Barley & $9916.0-13,875.0$ & $0.9-1.8$ & $8924.4-24,975.0$ & $40.0 \%$ & $3569.7-9990.0$ \\
\hline Rapeseed & $516.0-683.0$ & $1.1-1.7$ & $567.6-1161.1$ & $50.0 \%$ & $283.8-580.6$ \\
\hline $\begin{array}{l}\text { Animal } \\
\text { type }\end{array}$ & $\begin{array}{l}\text { Annual range of animal } \\
\text { population } \\
\text { (Central Bureau } \\
\text { of Statistics-CBS 2009-2011 for } \\
\text { Overijssel province) }(t)\end{array}$ & $\begin{array}{l}\text { Average } \\
\text { manure } \\
\text { ield }(t) \text { per } \\
\text { animal } \\
\text { per year }\end{array}$ & $\begin{array}{l}\text { Potential } \\
\text { biomass } \\
\text { yield } \\
(2009-2011)(t)\end{array}$ & $\begin{array}{l}\% \text { Available for } \\
\text { bioenergy } \\
\text { production [54] }\end{array}$ & $\begin{array}{l}\text { Potential biomass } \\
\text { available for } \\
\text { bioenergy production } \\
\quad(2009-2011)(t)\end{array}$ \\
\hline Beef cattle & $179,349.0-188,432.0$ & 12.3 & $2,198,819.0-2,310,176.0$ & $10.0 \%$ & $219,881.9-231,017.6$ \\
\hline Dairy cattle & $435,2960.0-445,973.0$ & 20.3 & $8,840,862.0-9,057,712.0$ & $88.0 \%$ & $7,779,958.0-7,970,786.0$ \\
\hline Pig & $1,651,501.0-1,663,583.0$ & 3.3 & $5,433,438.0-5,473,188.0$ & $50.0 \%$ & $2,716,719.0-2,736,594.0$ \\
\hline Chicken & $10,022,750.0-10,631,637.0$ & 0.04 & $400,910.0-425,265.5$ & $80.0 \%$ & $320,728.0-340,212.4$ \\
\hline
\end{tabular}

\begin{tabular}{|c|c|c|c|}
\hline Input energies & $\begin{array}{l}\text { Early harvest } \\
\text { scheme (GJ) }\end{array}$ & $\begin{array}{l}\text { Intermediate harvest } \\
\text { scheme (GJ) }\end{array}$ & $\begin{array}{l}\text { Late harvest } \\
\text { scheme (GJ) }\end{array}$ \\
\hline Cultivation & $1051.5-1733.7$ & $466.8-769.7$ & $117.1-193.1$ \\
\hline Fertilizer production: $\mathrm{N}$ & 0.0 & 0.0 & 0.0 \\
\hline Fertilizer production: $\mathrm{P}$ & $113.1-186.5$ & $100.6-165.8$ & $31.4-51.8$ \\
\hline Fertilizer production: $\mathrm{K}$ & $288.3-475.3$ & $256.2-422.5$ & $80.1-132.0$ \\
\hline Total Energy for Fertilizer Production & $401.4-661.8$ & $356.8-588.3$ & $111.5-183.8$ \\
\hline Crop protection chemicals: Insecticides & $117.2-193.2$ & $104.2-171.7$ & $32.6-53.7$ \\
\hline Crop protection chemicals: Herbicides & $117.2-193.2$ & $104.2-171.7$ & $32.6-53.7$ \\
\hline Crop protection chemicals: Fungicides & $117.2-193.2$ & $104.2-171.7$ & $32.6-53.7$ \\
\hline Total Energy for Crop Protection Chemicals & $351.5-579.6$ & $312.5-515.2$ & $97.7-161.0$ \\
\hline Mowing and chopping & $151.8-250.3$ & $101.2-166.9$ & $50.6-83.4$ \\
\hline Baling and stacking & $74.8-123.3$ & $49.9-82.2$ & $24.9-41.1$ \\
\hline Transportation & $43.5-71.7$ & $58.0-96.7$ & $36.3-59.8$ \\
\hline Human labour & 4.2 & 4.2 & 4.2 \\
\hline Wet oxidation process & $2.3-3.7$ & $3.0-5.0$ & $1.9-3.1$ \\
\hline Biogas plant operation & $130.5-215.2$ & $174.0-287.0$ & $108.8-179.4$ \\
\hline Total Input Energy & $2211.6-3643.7$ & $1526.5-2514.1$ & $552.9-908.9$ \\
\hline Output energies & Early & Intermediate & Late \\
\hline Biogas & $4405.5-7263.6$ & $5874.0-9685.0$ & $3671.2-6053.0$ \\
\hline Fibre co-digestate-N & $49.0-80.7$ & $65.3-107.6$ & $40.8-67.3$ \\
\hline Fibre co-digestate-P & $66.8-110.2$ & $89.1-146.9$ & $55.7-91.8$ \\
\hline Fibre co-digestate- $\mathrm{K}$ & $6.8-11.2$ & $9.1-15.0$ & $5.7-9.3$ \\
\hline Total Energy from Fibre & $122.6-202.1$ & $163.5-269.5$ & $102.2-168.5$ \\
\hline Liquor co-digestate-N & $107.4-177.1$ & $143.2-236.1$ & $89.5-147.6$ \\
\hline Liquor co-digestate-P & $6.3-10.3$ & $8.4-13.8$ & $5.2-8.6$ \\
\hline Liquor co-digestate- $\mathrm{K}$ & $39.8-65.6$ & $53.0-87.5$ & $33.2-54.7$ \\
\hline Total Energy from Liquor & $153.5-253.0$ & $204.6-337.3$ & $127.9-210.8$ \\
\hline Total Energy from Digestate & $276.1-455.1$ & $368.1-606.9$ & $230.0-379.3$ \\
\hline Total Output energy & $4681.5-7718.9$ & $6242.0-10,291.9$ & $3901.0-6432.4$ \\
\hline Net Energy Gain (NEG) & $2470.0-4075.0$ & $4715.6-7777.8$ & $3348.0-5523.5$ \\
\hline NEG per Hectare & 32.7 & 62.4 & 44.3 \\
\hline NEG per tonne of biomass & 5.5 & 7.8 & 8.9 \\
\hline Energy Return on Energy Invested (EROEI) & 2.1 & 4.1 & 7.1 \\
\hline
\end{tabular}


Table 6 - Bioenergy production from mowing natural grasslands: potential input energies, output energies, NEG in GJ and EROEI (2009-2011).

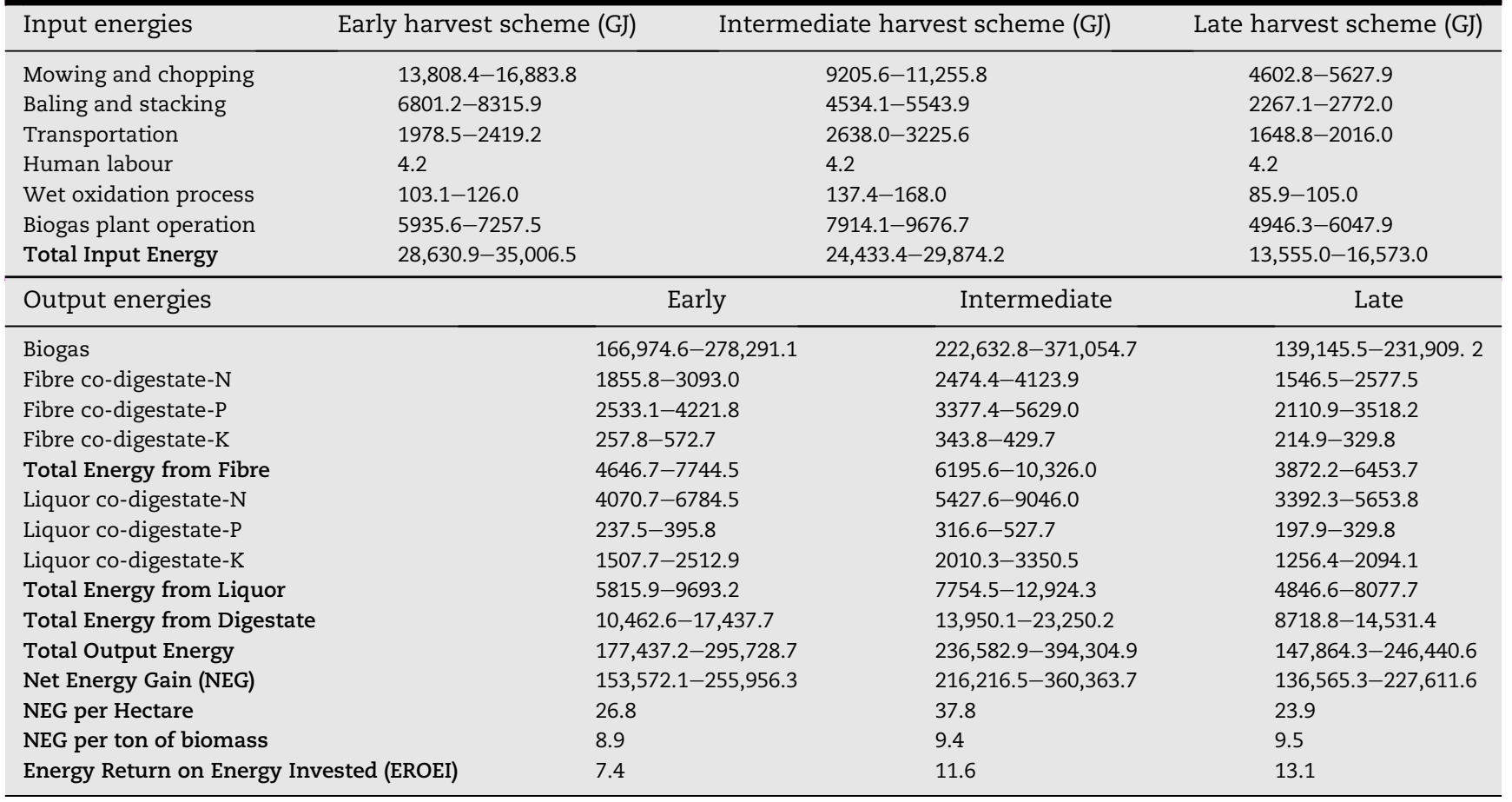

protection chemicals compared to what is produced in terms of energy. Although a higher net energy gain is obtainable under the intermediate harvest scheme, far less energy is needed to reap considerably higher net energy gain under the late scheme. As shown in Table 6, all the harvest schemes under the natural grassland option were energy efficient. Although the late harvest scheme is about $72.6 \%$ more energy efficient than the intermediate harvest scheme and about $233 \%$ more energy efficient than the early harvest scheme, it may however not be feasible because of the natural grassland management policy of the Netherlands. It prescribes that nutrient-rich grasslands should be mowed two or three times annually; while nutrient-poor grasslands should be mowed once annually $[36,37,56]$. Consequently, the next most energy efficient and most feasible harvest scheme, which also gives the highest net energy gain on the natural grassland is the intermediate harvest scheme.

The EROEIs of the different grass harvest schemes hardly change, even under the influence of $\pm 20 \%$ classification error. As seen in Table 6, the EROEI of the different grass harvest schemes remains the same, but the NEG changes with changing number of harvest times, and correspondingly changing biomass/energy yields. This is because the influence of the error evens out as the output is being divided by the input. Consequently, as shown in Fig. 3, the error level of the NEG estimates for the different grass harvest schemes increases with increase in the number of harvest times and corresponding increase in the biomass/energy yield. The late harvest scheme with just one harvest and the least biomass/ energy yield has the least error level, while the intermediate harvest scheme with two harvests and the highest biomass/ energy yield has the highest error level, because uncertainties where propagated continually with more harvests and higher biomass/energy yield.

Farm manure from dairy cattle as seen in Table 7 has a relatively low EROEI value. The energy input for manure collection, storage and haulage is quite high. Despite the low energy efficiency this biomass resource has the largest single net energy gain in rural Overijssel (31.3-32.1 PJ). This can be attributed to the high NEG per animal value of $71.9 \mathrm{GJ}$ and a high total manure yield in the whole province.

Table 8 shows an estimate of the energy efficiency, net energy obtainable and the energy involved in obtaining bioenergy from crop residues. Of the rural biomass sources considered by this study, maize residues had the highest energy efficiency and NEG per hectare (EROEI of 15.7-17, and an

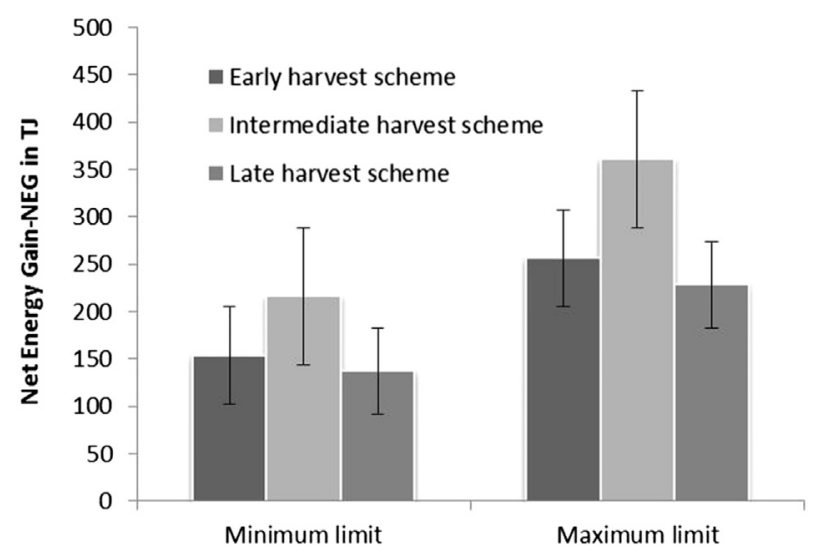

Fig. 3 - Error range of NEG estimation for grasses from natural grasslands. 
Table 7 - Bioenergy production from farm manure: potential input energies, output energies, NEG in GJ and EROEI (2009-2011).

\begin{tabular}{|c|c|c|c|c|}
\hline Input energies & Beef cattle (GJ) & Dairy cattle (GJ) & Pigs (GJ) & Chickens (GJ) \\
\hline $\begin{array}{l}\text { Manure collection, } \\
\text { storage and haulage }\end{array}$ & $43,976.4-46,203.5$ & $7,079,762.1-7,253,415.5$ & $706,347.0-711.514 .5$ & $11,546.2-12,247.7$ \\
\hline Transportation & $61,566.9-64,684.9$ & $2,178,388.3-2,231,820.1$ & $760,681.4-766,246.3$ & $89,803.8-95,259.5$ \\
\hline Human labour & 4.2 & 4.2 & 4.2 & 4.2 \\
\hline Wet oxidation process & $1099.4-1155.1$ & $38,899.8-39,853.9$ & $13,583.6-13,683.0$ & $1603.6-1701.1$ \\
\hline Biogas plant operation & $63,326.0-66,533.1$ & $2,240,628.0-2,295,586.4$ & $782,415.1-788,139.1$ & $92,369.7-97,981.2$ \\
\hline Total Input Energy & $169,973.0-178,580.8$ & $11,537,682.4-11,820,680.2$ & $2,263,031.3-2,279,587.0$ & $195,327.6-207,193.5$ \\
\hline Output energies & Beef cattle & Dairy cattle & Pig & Chicken \\
\hline Biogas & $1,076,555.1-1,131,076.5$ & $38,091,152.2-39,025,457.2$ & $2,425,5025.0-24,432,469.2$ & $2,678,701.8-2,841,434.2$ \\
\hline Fibre co-digestate-N & $23,753.6-24,956.6$ & $840,459.6-861,074.5$ & $293,483.9-295,631.0$ & $34,647.9-36,752.7$ \\
\hline Fibre co-digestate-P & $32,422.9-34,064.9$ & $1,147,201.5-1,175,340.3$ & $400,596.5-403,527.2$ & $47,293.3-50,166.4$ \\
\hline Fibre co-digestate-K & $3300.3-3467.5$ & $116,774.1-119,638.3$ & $40,776.9-41,075.2$ & $4814.0-5.106 .5$ \\
\hline Total Energy from Fibre & $59,476.8-62,489.0$ & $2,104,435.2-2,156,053.0$ & $734,857.3-740,233.4$ & $86,755.1-92,025.5$ \\
\hline Liquor co-digestate-N & $52,104.6-54,743.4$ & $1,843,588.7-1,888,808.5$ & $643,771.2-648,480.8$ & $76,001.8-80,618.9$ \\
\hline Liquor co-digestate-P & $3039.7-3193.6$ & $107,550.1-110,188.1$ & $37,555.9-37,830.7$ & $4433.7-4703.1$ \\
\hline Liquor co-digestate-K & $19,298.6-20,276.0$ & $682,831.4-699,580.0$ & $238,441.0-240,185.4$ & $28,149.7-29,859.8$ \\
\hline Total Energy from Liquor & $74,442.9-78,213.0$ & $2,633,970.3-2,698,576.6$ & $919,768.1-926,496.9$ & $108,585.2-115,181.8$ \\
\hline Total Energy from Digestate & $133,919.7-140,701.9$ & $4,738,405.4-4,854,629.7$ & $1,654,625.4-1,666,730.3$ & $195,340.3-207,207.3$ \\
\hline Total Output Energy & $1,210,474.8-1,271,778.4$ & $42,829,557.6-43,880,086.9$ & $25,909,650.4-26,099,199.4$ & $2,874,042.1-3,048,641.5$ \\
\hline Net Energy Gain (NEG) & $1,040,502.0-1,093,197.6$ & $31,291,875.2-32,059,406.7$ & $23,646,619.2-23,819,612.4$ & $2,678,714.5-2,841,448.0$ \\
\hline NEG per Animal & 5.8 & 71.9 & 14.3 & 0.3 \\
\hline NEG per tonne of biomass & 4.7 & 4.0 & 8.7 & 8.4 \\
\hline $\begin{array}{l}\text { Energy Return on Energy } \\
\text { Invested (EROEI) }\end{array}$ & 7.1 & 3.7 & 11.4 & 14.7 \\
\hline
\end{tabular}

NEG per hectare of 104.5-184.5 GJ). It also had the highest NEG amongst the crop residues (4.5-8.4 PJ).

In Table 9, we review the bioenergy potential in relation to the 2030 targets in the province of Overijssel. The total NEG from biogas can produce enough electricity, heat and transport fuel to cover Overijssel's renewable energy targets from bioenergy sources by the year 2030. About 2.4-4.5 PJ of energy from biogas can be further used for the production of either transport fuel or heat and electricity.

\section{Discussion}

Under existing conditions, farm manure accounts for $89.56 \%$ of NEG obtainable in rural Overijssel; crop residue contributes about 9.99\%; grasses from natural grasslands - about $0.44 \%$ and surplus pasturelands give about $0.01 \%$. This is certainly very much driven by the flows of biomass available, and can change if agricultural practice change. For example, if meat consumption declines under the pressure of medical (rise in rates of obesity and other meat induced diseases) or sustainability (high ecological footprint) concerns the picture will change. In that case we may find an increasing role of crop residues in the overall mix of bioenergy. Dairy manure is the biomass source with the highest single NEG, its efficiency (EROEI) can however be optimized by co-digestion with other types of manure and biomass since co-digested biomass is known to produce more energy than mono-digested ones [41]. The co-digestion of pig manure with other types of biomass will not conflict with phosphate recovery from pig manure, because resulting digestate can be further processed for the recovery of phosphate and many other valuable minerals [37,57]. The biomass yield and energy efficiency of cattle manure (dairy and beef cattle) for bioenergy production can also be improved by making cattle stay longer in barns and on hard surfaces. This will however be in conflict with the goal of keeping cattle longer on meadows to improve their health and well-being [58]. This may stir huge controversies between actualizing the energy targets and protecting animal health and welfare, with stakeholders from animal right organizations in conflict with organizations promoting biogas/bioenergy production [59]. However, the fact that almost $90 \%$ or more energy can be expected to come from manure, tells us about where we should focus our efforts, both in terms of investment of money and ideas, and in terms of improving the accuracy of our assessment. Also, new priorities related to renewable energy and energy efficiency might give more weight to the consideration of regulations and policies that favours late grass harvest scheme over more feasible and energy productive (higher NEG value) intermediate grass harvest scheme in the long run.

All biomass sources considered in this study were energy efficient although the early harvest scheme of surplus pastures is on the edge (EROEI value of 2.1). Fig. 4 shows that aside from dairy manure (with an EROEI of 3.7) the average lower limit of EROEI for by-products considered by this study is about 7. Conversely, the upper limit of EROEI for growing alfalfa feedstock on surplus pasturelands (late harvest scheme) is also around 7; the other harvest schemes under this option (intermediate and early harvest schemes) have a downward trend in energy inefficiency (EROEI values below 3). As seen in Fig. 4, the efficiencies (EROEI) of bioenergy sources in rural 
Table 8 - Bioenergy production from crop residues: potential input energies, output energies, NEG in GJ and EROEI (2009-2011).

\begin{tabular}{|c|c|c|c|c|c|c|c|}
\hline Input energies & Maize (GJ) & Rye (GJ) & Triticale (GJ) & Wheat (GJ) & Oat (GJ) & Barley (GJ) & Rapeseed (GJ) \\
\hline Stalk shredding & $10,867.0-11,443.3$ & $86.0-114.0$ & $113.0-171.5$ & $517.3-626.8$ & $12.0-23.3$ & $451.0-563.5$ & $32.5-36.3$ \\
\hline Mowing and chopping & $28,430.1-30,668$ & $230.5-305.5$ & $302.8-459.6$ & $1386.2-1679.7$ & $32.2-62.3$ & $1208.7-1510.2$ & $87.1-97.2$ \\
\hline Baling and stacking & $14,003.0-15,105.1$ & $113.5-150.5$ & $149.2-226.4$ & $682.8-827.3$ & $15.8-30.7$ & $595.3-743.8$ & $42.9-47.9$ \\
\hline Transportation & $62,798.0-116,218.0$ & $100.7-158.8$ & $56.8-264.2$ & $323.9-1239.0$ & $9.1-31.7$ & $342.7-959.0$ & $27.2-55.7$ \\
\hline Human labour & 4.2 & 4.2 & 4.2 & 4.2 & 4.2 & 4.2 & 4.2 \\
\hline Wet oxidation process & $3270.7-6053.0$ & $5.2-8.3$ & $3.0-13.8$ & $16.9-64.5$ & $0.5-1.7$ & $17.8-50.0$ & $1.4-2.9$ \\
\hline Biogas plant operation & $188,394.0-348,654.0$ & $302.0-476.4$ & $170.5-792.5$ & $371.6-3716.9$ & $27.3-95.2$ & $1028.1-2877.1$ & $81.7-67.2$ \\
\hline Total Input Energy & $308,802.0-528,146.0$ & $842.1-1217.6$ & $799.5-1883.4$ & $3902.8-8158.4$ & $101.1-240.2$ & $3647.8-6707.8$ & $277.1-400.0$ \\
\hline Output energies & Maize & Rye & Triticale & Wheat & Oat & Barley & Rapeseed \\
\hline Biogas & $\begin{array}{l}4,450,808.0-8,236 \\
956.4\end{array}$ & $\begin{array}{l}7134.4-11 \\
254.5\end{array}$ & $\begin{array}{l}4028.5-18 \\
723.5\end{array}$ & $\begin{array}{l}22,954.5-87 \\
812.4\end{array}$ & $645.0-2248.0$ & $24,288.6-67,972.0$ & $1931.0-3950.1$ \\
\hline Fibre co-digestate-N & $70,666.6-130,780.2$ & $113.3-178.7$ & $64.0-297.3$ & $364.5-1394.2$ & $10.2-35.7$ & $385.6-1079.2$ & $30.7-62.7$ \\
\hline Fibre co-digestate-P & $96,457.7-178,511.0$ & $154.6-243.9$ & $87.3-405.8$ & $497.5-1903.1$ & $14.0-48.7$ & $526.4-1473.1$ & $41.8-85.6$ \\
\hline Fibre co-digestate-K & $9818.5-18,170.7$ & $15.7-24.8$ & $8.9-41.3$ & $50.6-193.7$ & $1.4-5.0$ & $53.6-149.9$ & $4.3-8.7$ \\
\hline Total Energy from Fibre & $176,942.8-327,461.9$ & $283.6-447.4$ & $160.2-744.4$ & $912.6-3491.0$ & $25.6-89.4$ & $965.6-2702.2$ & $76.8-157.0$ \\
\hline Liquor co-digestate-N & $155,010.6-286,872.7$ & $248.5-392.0$ & $140.3-652.1$ & $799.4-3058.3$ & $22.5-78.3$ & $845.9-2367.3$ & $67.3-137.6$ \\
\hline Liquor co-digestate-P & $9043.0-16,735.4$ & $14.5-22.9$ & $8.2-38.0$ & $46.6-178.4$ & $1.3-4.6$ & $49.3-138.1$ & $3.9-8.0$ \\
\hline Liquor co-digestate-K & $57,413.1-106,252.4$ & $92.0-145.2$ & $52.0-241.5$ & $296.1-1132.7$ & $8.3-29.0$ & $313.3-876.8$ & $24.9-51.0$ \\
\hline $\begin{array}{l}\text { Total Energy from } \\
\text { Liquor }\end{array}$ & $221,466.6-409,860.5$ & $355.0-560.0$ & $200.5-931.7$ & $1142.2-4369.4$ & $32.1-111.9$ & $1208.6-3382.2$ & $96.1-196.6$ \\
\hline $\begin{array}{l}\text { Total Energy from } \\
\text { Digestate }\end{array}$ & $398,409.3-737,322.4$ & $638.6-1007.4$ & $360.6-1676.0$ & $2054.7-7860.4$ & $57.7-201.2$ & $2174.2-6084.4$ & $172.8-353.6$ \\
\hline Total Output energy & $\begin{array}{l}4,849,217.4-8,974, \\
278.8\end{array}$ & $\begin{array}{l}7773.0-12, \\
262.0\end{array}$ & $\begin{array}{l}4389.1-20 \\
399.5\end{array}$ & $\begin{array}{l}25,009.3-95 \\
672.9\end{array}$ & $702.8-2449.3$ & $26,462.8-74,056.4$ & $2103.8-4303.6$ \\
\hline Net Energy Gain (NEG) & $\begin{array}{l}4,540,415.4-8,446 \\
133.0\end{array}$ & $\begin{array}{l}6930.9-11 \\
044.3\end{array}$ & $\begin{array}{l}3589.6-18 \\
516.1\end{array}$ & $\begin{array}{l}21,106.5-87 \\
514.5\end{array}$ & $601.7-2209.0$ & $22,815.0-67,348.6$ & $1826.7-3903.6$ \\
\hline NEG per Hectare & $104.5-184.5$ & $20.1-24.2$ & $7.9-28.6$ & $10.2-34.9$ & $12.5-25.7$ & $12.6-29.9$ & $14.1-28.7$ \\
\hline $\begin{array}{l}\text { NEG per tonne of } \\
\text { biomass }\end{array}$ & $6.9-7.0$ & $6.6-7.0$ & $6.1-6.7$ & $6.3-6.8$ & $6.3-6.7$ & $6.4-6.7$ & $6.4-6.7$ \\
\hline $\begin{array}{l}\text { Energy Return on } \\
\text { Energy Invested } \\
\text { (EROEI) }\end{array}$ & $15.7-17.0$ & $8.7-10.1$ & $5.1-10.8$ & $6.3-11.7$ & $6.4-10.2$ & $7.1-11.0$ & $7.6-10.8$ \\
\hline
\end{tabular}

areas are close to what we currently have for fossil fuels and other renewable energy sources [60,61]. This makes it even more desirable and urgent to invest in this kind of bioenergy production in the province.

We have shown that potentially there are technologies and biomass sources in the province to produce a NEG of 62.9-68.1 PJ out of which more than $99 \%$ will come from crop residues and farm manure. Less than 1\% will come from grasslands and pasturelands. About $91 \%$ out of the NEG will be from the biogas produced, while the remaining $9 \%$ will be from digestate if used as fertilizer replacement.

In addition to producing energy to meet the provincial targets, there are other benefits. An additional 12.9-17.4 PJ worth of heat can be added by the Overijssel province to bioenergy targets elsewhere within the EU, if the combined heat and power generation (CHP) technology is used. The digestates from wet anaerobic co-digestion of different types of biomass (farm manure, crop residue and grasses) can act as industrial raw material for the production of chemical fertilizers or can replace chemical fertilizers directly on farmlands $[41,46,62]$. The NEG from digestates can replace about $59.4 \%$ of energy needed to produce these chemicals. Although this is quite substantial, fertilizer is not the only chemical that will be needed. Other chemicals such as pesticides, herbicides, fungicides, plastics, rubber etc. will still be required. Replacing fossil fuels with biogas (indirect agricultural and transport emissions not considered) will save an estimated 5.3-6.6 Mt of $\mathrm{CO}_{2}$ if combined heat and electricity generation technology is used; about 4.9-5.2 $\mathrm{Mt}$ of $\mathrm{CO}_{2}$ can also be saved if biogas is used for the production of transport fuels [39]. The natural gas

\section{Table 9 - Evaluation of Overijssel's 2030 bioenergy potential.}

\begin{tabular}{lccc} 
Form of energy & $\begin{array}{c}2030 \text { bioenergy } \\
\text { target (60.0 PJ) }\end{array}$ & $\begin{array}{c}\text { Optimum conversion } \\
\text { efficiency of biogas [62] }\end{array}$ & $\begin{array}{c}\text { Bioenergy potential NEG- } \\
(63.9-68.4 \text { PJ) }\end{array}$ \\
\hline Transport fuel & $23.0 \mathrm{PJ}$ & $96.0 \%$ & $23.0 \mathrm{PJ}$ \\
Heat (CHP) & $13.0 \mathrm{PJ}$ & $70.0 \%$ & $28.0 \mathrm{PJ}$ \\
Electricity (CHP) & $14.0 \mathrm{PJ}$ & $35.0 \%$ & $14.0 \mathrm{PJ}$ \\
Industrial raw material & $10.0 \mathrm{PJ}$ & As liquid fertilizer & $+12.9-17.4 \mathrm{PJ}$ of heat \\
\hline
\end{tabular}




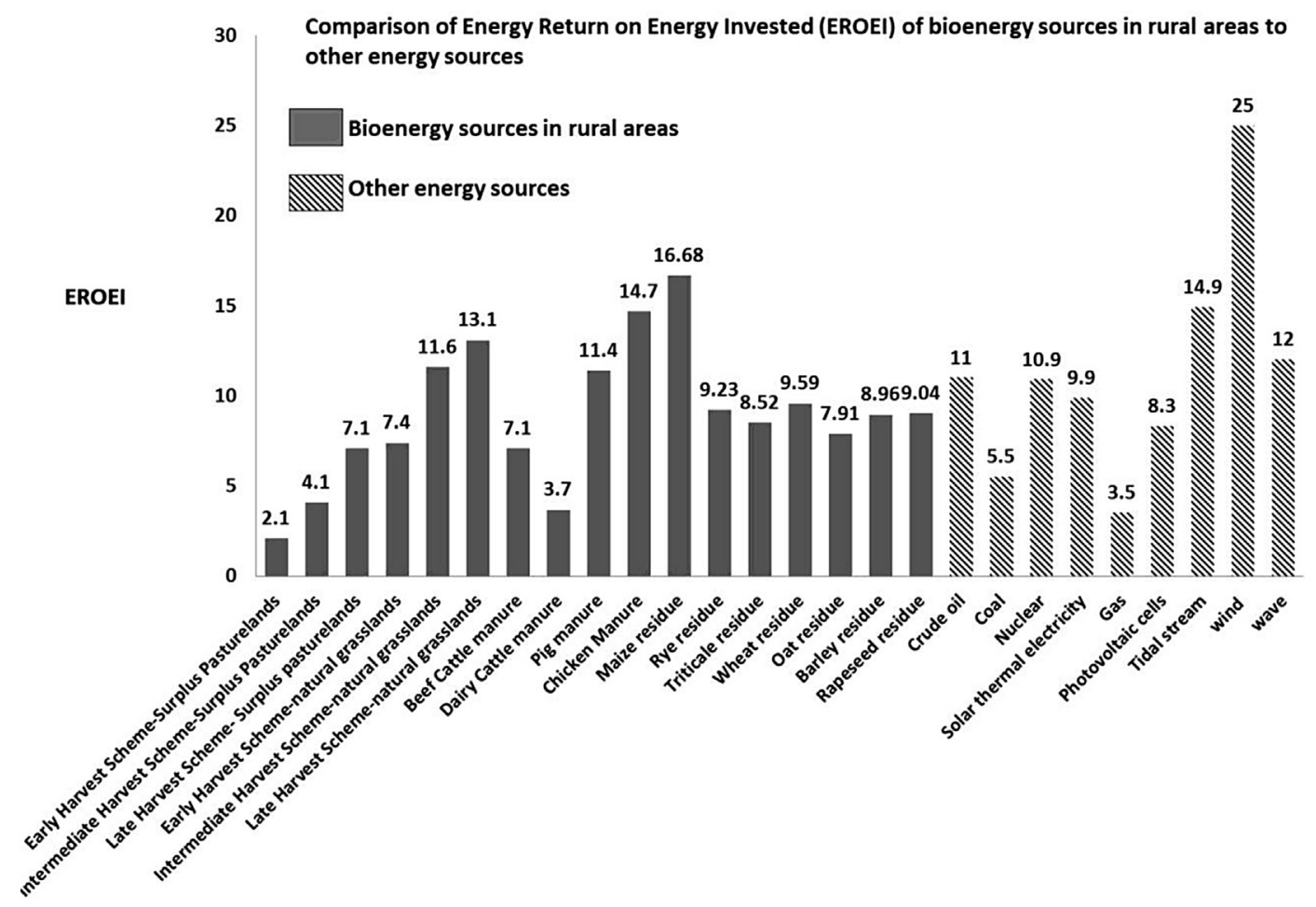

Fig. 4 - Comparison of Energy Return on Energy Invested (EROEI) of bioenergy produced from various sources in rural areas to other energy sources $[60,61]$.

equivalent of the NEG obtainable from rural Overijssel is about 38.3-41 PJ, while fossil fuel replacement is about 62.8-67.0 PJ [48].

However, the implementation of these strategies is not as easy as one would wish if sustainability constraints are factored in. There is still much infrastructural and policy changes that need to be implemented. Under existing Dutch laws there are strict regulations on the amount of manure that can be applied on land, and digestate is seen no different than manure [31]. These manure application quotas are currently all taken up by farmers, for whom it is the cheapest way to dispose of manure. Taking manure to the digesters at current transportation and processing costs is a net loss for the farmers, and it is done only for the manure that exceeds the disposal quotas. This is especially the case for intensive confined agriculture (pig or chicken farms), where there is no land available to dispose of manure. This leaves very little space for the utilization of digestate, which in our calculations is a net benefit, an energy source, rather than sink. If the existing subsidy arrangements and policies where changed, making it impossible to apply manure directly, until it is processed by biodigesters, then this could significantly change the bioenergy production landscape, creating new opportunities and benefits. Another unknown source of uncertainty is the time for which manure or biomass are stored before entering the bio-digester. On its way from the cow to the biogas processing unit, the biomass can lose up to $40 \%$ of the volume of methane contained in it (Prinsen, personal communication). It is therefore much more efficient to bring the bio-digesters as close to the farms as possible. This can be beneficial in a variety of ways, decreasing the transportation costs and losses, increasing the methane output and providing more direct uses for bioenergy on the farm (household or greenhouse uses, running small machinery, etc.).

However installing new small-scale bio-digesters can take time and will require new investments and technologies. It is also to be decided how the excess biogas will be used: liquefaction for transportation use (additional processing and technologies required), feeding into biogas pipeworks (yet to be built), etc. The biogas currently produced in existing biodigesters is $55-75 \%$ methane and $25-45 \%$ carbon dioxide by volume [40]. This is considerably lower than the standard accepted in existing pipelines and devices built for natural gas (with more than $95 \%$ methane concentration) $[48,63,64]$. This means that additional energy is needed to refine and upgrade the biogas produced to the required standards. Alternatively, parallel gas pipelines and improved gas burning devices could be developed; both options are however associated with upfront energy investments that will impact the overall efficiency of the proposed approach. Currently most bio-digesters use biogas to produce electricity on-site using stationary internal combustion generators. This has quite low efficiency but can be optimized if waste heat from engine cooling and exhaust gases is recovered and used for heat and electricity cogeneration. The use of biogas is also associated with leakage of methane (a potent greenhouse gas) to the atmosphere [64]. Technological innovations that can improve the efficiency of biogas in terms of use, reduction of $\mathrm{CO}_{2}$ emissions and $\mathrm{CH}_{4}$ leakages across its production chain should be prioritized. 
However, this also will not come without extra energy costs and investments.

There will also be need to increase the capacity of the existing digesters for wet anaerobic co-digestion of the vast mix of biomass resource available. However, another problem with the process is that agrochemicals (from crop residues) and/or animal concentrates/steroids (from farm manure) can cause reduction of biogas yield, transition of trace elements (e.g. copper, zinc etc.) into digestates and subsequent introduction into soils, ground and nearby surface waters beyond safe levels $[40,65]$. Excess trace elements in soils can result in deficiency of some vital elements in soils (e.g. iron), inhibit plant growth and affect human nutrient absorption cycles adversely [66].

If some of these issues that threaten the sustainability of the biomass/bioenergy production activities in rural areas can be resolved, rural Overijssel and rural areas within the EU can produce sufficient renewable energy to reach the 2020 bioenergy targets [29].

The use of EROEI, NEG and other derivatives offers alternatives aimed at minimizing constraints to bioenergy production and maximizing its potential outputs. The alternatives for bioenergy production within the Overijssel province include:

- Increased exploitation of waste material from farm operations e.g. farm manure, crop residue, silage from mown grasslands etc. as opposed to indefinite search for land for planting of designated bioenergy crops.

- The use of farm-scale wet anaerobic co-digestion as biomass production technology for all wet biomass types. This is because of the ease of co-digestion of different biomass types, increase in efficiency as a result of proximity of biomass sources to digesters, and the opportunity it offers for mineral nutrient recovery [42].

- Better animal management options and farm structure technologies for increased energy efficiency.

We estimated the energy output of different types of biomass (grasses, straw and manure) individually. While the uncertainties associated with future technologies and policy making allows us to talk only about potential energy production and best-case scenario, our estimates themselves are quite conservative. Much more energy than the energy of the individual biomass types can be obtained from the wet anaerobic co-digestion of manure, grass and straw biomass $[40,42]$. Besides, there are many other promising sources of "sustainable" bioenergy from urban, residential, natural and waste lands, which we treated in a separate study [67]. An appropriate energy reference system for wet anaerobic co-digestion of manure, grass and straw biomass will give more precise estimates of the potential energy output from this technology. Most of the estimates from this study were based on the 2009-2011 data of the Central Bureau of Statistics (CBS). This includes variables such as annual crop yield, annual animal population, area under cultivation and area under surplus pasturelands etc. These statistics are subject to annual changes. However, over the three years used in this study we did not see very high variations.
Errors might have been propagated in the course of this study, and this could have been a product of one or a combination of any of the following four sources namely:

- Uncertainties arising from the use of conversion factors and coefficients from different reference systems from different EU countries and the US.

- Errors arising from assumptions as a result of nonavailability of certain conversion factors and coefficients.

- Double counting errors arising from an overlap in certain energy investment (input) activities e.g. energy for stalk shredding of crop residues and energy for mowing and chopping of crop residues.

We are also uncertain about the actual acceptance of the suggested changes in the agricultural practices, where certain product flows will have to be modified. Energy efficient animal management operations and housing designs can further enhance potential biomass yield of farm manure (beef cattle and pigs). More efficient manure collection solutions such as piping manure from source to nearby digesters can help optimize the net energy gains from dairy manure and increase its energy efficiency. This could be a subject of future building technology or agricultural engineering research. The use of well distributed and strategically located farm-scale wet co-digesters for bioenergy production can help harness the relatively large bioenergy potential available [68]. This can be done by putting the necessary locational factors into consideration e.g. proximity to raw materials (biomass sources), proximity to residential areas (air pollution concerns) etc. [42].

The accuracy of some of the conversion factors and coefficients is also unknown. Average values were most frequently used. Although this gave fair estimates of the bioenergy potential of the various biomass/bioenergy production activities under study, it is difficult to establish the range of uncertainties involved in some of the estimations. Errors arising from assumptions are not expected to produce outliers, because such assumptions were based on similar processes or production chains. Errors arising from double counting of energy inputs can be ignored because some of the overlap actually exists in real life biomass/bioenergy production activities.

The use of by-products as bioenergy sources generally comes out as more efficient because it saves energy on the input side. Since the goal of the production is not bioenergy we do not need to account for the energy used. On the contrary, planting of designated bioenergy crops uses large amounts of energy. As a result, even though they may produce large stocks of biomass, they produce little, zero or negative net energy. Therefore, the use of by-products, which does not involve the full production cycle should be prioritized for increased efficiency and net energy gains. The factors that are responsible for annual variations in biomass yield, NEG and EROEI of biomass sources differ spatially. Such factors may include farmer's management practices and decisions, economic or market forces, climate variations, incidences of pest and diseases etc. However, the impacts of such factors locally within the Overijssel province are not well known, and these can also be a subject of future research. 


\section{Conclusions}

The use of available land, monetary valuation, biomass yield and energy output alone in bioenergy analysis is inadequate and may be misleading. Some agricultural practices may be subsidized or may use much conventional fossil fuels for production, totally skewing the real picture of energy output. They may be economically profitable under existing policies and market conditions, but still unsustainable in the long run. Incorporating energy efficiency indices into environmental assessments opens up new possibilities aimed at minimizing constraints to bioenergy production and maximizing its potential output. EROEI is the energy efficiency, and deliberately gives advantage to production chains that use less on the input side. NEG is useful to evaluate the significance of total energy obtainable, when for example we need to analyse the feasibility of the set renewable energy targets. Since NEG factors in the energy input it is more accurate in assessing the feasibility of set renewable energy targets than using potential energy yield as mostly practised. While potential energy yield may give a false impression that an energy source is very productive, a consideration of the energy input using the NEG index may give a clearer picture of the actual potential of the energy production activity in terms of the set renewable energy targets. Using the EROEI index together with the NEG (a NEG-EROEI approach) further adds scientific rigour to the energy input-output analysis given room for a broader spectrum of analysis for improvement of the efficiency of energy production chains as done by this study (energy sources on one hand and energy production technologies on the other hand). This study further underlines the importance of the NEGEROEI approach as a valuable impact assessment indicator and tool, as was discussed in a separate publication [69]. Most of the coefficients and the methodology in general can be easily adapted beyond the province of Overijssel, for the Netherlands as a whole and the EU as long as the basic agricultural practices and energy conversion technologies are the same.

We may conclude by stating that the EU 2020 targets for renewable energy can potentially be met if there is adequate focus on harnessing by-products (especially farm manure and crop residues) and concerted efforts between engineers (technologists) and policy makers. In addition to some tweaking of existing technologies and investments in new infrastructure, this will require a substantial push towards acceptance of new policies, management schemes and farm operations, which will be hard to achieve without appropriate subsidies and incentives.

\section{Acknowledgements}

Funding from the Erasmus Mundus program was instrumental in supporting the first author. His thanks are also due to Olukemi Abimbola Arodudu for her financial contribution to his research work. A. Voinov was partially supported by the BE2.O (Bioenergy for Overijssel) project. We are very grateful to Maarten Arentsen for his advice and help, and acknowledge the contributions of Thomas Hoppe, and other
BE2.O researchers for their contribution towards the success of this work. We also want to say a big thank you to Veepro Holland Information centre for Dutch cattle for their permission to use one of their manuals as a reference for this work.

\section{Appendix A. Supplementary data}

Supplementary data related to this article can be found at http://dx.doi.org/10.1016/j.biombioe.2013.07.020.

\section{R E F E R E N C E S}

[1] Meinshausen M, Meinshausen N, Hare W, Raper SCB, Frieler K, Knutti R, et al. Greenhouse-gas emission targets for limiting global warming to $2{ }^{\circ} \mathrm{C}$. Nature 2009;458(7242):1158-62.

[2] Ng JH, Ng H, Gan S. Recent trends in policies, socioeconomy and future directions of the biodiesel industry. Clean Technol Environ Policy 2010;12(3):213-38.

[3] UNFCCC. Kyoto protocol reference manual on accounting of emissions and assigned amount. Bonn (Germany): United Nations Framework Convention on Climate Change (UNFCCC); 2008 Nov. p. 130.

[4] European Commission. Renewable energy: national renewable energy action plans. Brussels (Belgium): European Commission; 2012 Oct.. p. 23.

[5] Atanasiu B. The role of bioenergy in the national renewable energy action plans: a first identification of issues and uncertainties. Bonn (Germany): Institute for European Environmental Policy (IEEP); 2010 Nov. p. 23.

[6] Fischer G, Prieler S, van Velthuizen H, Berndes G, Faaij A, Londo M. Biofuel production potentials in Europe: sustainable use of cultivated land and pastures, part II: land use scenarios. Biomass Bioenergy 2010;34(2):173-87.

[7] Fiorese Guariso G. A GIS-based approach to evaluate biomass potential from energy crops at regional scale. Environ Model Softw 2010;25(6):702-11.

[8] Prochnow A, Heiermann M, Plöchl M, Linke B, Idler C, Amon $\mathrm{T}$, et al. Bioenergy from permanent grassland - a review: 1. Biogas Bioresour Technol 2009;100(21):4931-44.

[9] van der Hilst F, Dornburg V, Sanders JPM, Elbersen B, Graves A, Turkenburg WC. Potential, spatial distribution and economic performance of regional biomass chains: the North of the Netherlands as example. Agric Syst 2010;103(7):403-17.

[10] Cramer J, Hamelinck C, Maris J, Faaij A, Dornburg V, Sielhorst S, et al. Testing framework for sustainable biomass [Internet]. The Netherlands: Energy Transition's Interdepartmental Programme Management (IPM); 2007 Mar. p. 72 [cited 2011 Aug 23]. Available from: http://www.lowcvp. org.uk/assets/reports/070427-Cramer-FinalReport_EN.pdf.

[11] Lovett JC, Hards S, Clancy J, Snell C. Multiple objectives in biofuels sustainability policy. Energy Environ Sci 2011;4(2):261-8.

[12] Mekonnen MM, Hoekstra AY. The green, blue and grey water footprint of crops and derived crop products. Hydrol Earth Syst Sci 2011;15(5):1577-600.

[13] Gerbens-Leenes W, Hoekstra AY, van der Meer TH. The water footprint of bioenergy. Proc Natl Acad Sci U S A 2009;106(25):10219-23.

[14] Biemans M, Waarts Y, Nieto A, Goba V, Jones-Walters L, Zöckler C. Impacts of biofuel production on biodiversity in Europe [Internet]. Tilburg (Netherlands): European Centre for Nature Conservation; 2008 Oct. p. 32 [cited 2011 Sept 27]. 
Available from: http://www.ecnc.org/uploads/2012/10/2008biofuels.pdf.

[15] Ceotto E. Grasslands for bioenergy production: a review. Agron Sustain Develop 2008;28(1):47-55.

[16] Elobeid A, Tokgoz S, Dodder R, Johnson T, Kaplan O, Kurkalova L, et al. Integration of agricultural and energy system models for biofuel assessment. Environ Model Softw 2013;48(1):1-16.

[17] Prochnow A, Heiermann M, Plöchl M, Amon T, Hobbs PJ. Bioenergy from permanent grassland - a review: 2 . Combust Bioresour Technol 2009;100(21):4945-54.

[18] Hellmann F, Verburg PH. Spatially explicit modelling of biofuel crops in Europe. Biomass Bioenergy 2011;35(6):2411-24.

[19] Fischer G, Prieler S, van Velthuizen H, Lensink SM, Londo M, de Wit M. Biofuel production potentials in Europe: sustainable use of cultivated land and pastures. Part I: land productivity potentials. Biomass Bioenergy 2010;34(2):159-72.

[20] Beccali M, Columba P, D'Alberti V, Franzitta V. Assessment of bioenergy bioenergy potential in Sicily: a GIS-based support methodology. Biomass Bioenergy 2009;33(1):79-87.

[21] Hill J, Nelson E, Tilman D, Polasky S, Tiffany D. Environmental, economic, and energetic costs and benefits of biodiesel and ethanol biofuels. Proc Natl Acad Sci U S A 2006;103(30):11206-10.

[22] Hall CAS, Balogh S, Murphy DJR. What is the minimum EROI that a sustainable society must have? Energies 2009;2(1):25-47.

[23] Helming K, Diehl K, Bach H, Dilly O, König B, Kuhlman T, et al. Ex ante impact assessment of policies affecting land use, part A: analytical framework. Ecol Soc 2011;16(1):1-17.

[24] Voinov A, Farley J. Reconciling sustainability, systems theory and discounting. Ecol Econ 2007;63(1):104-13.

[25] CLC. CORINE land cover map of the Netherlands [map]. Copenhagen (Denmark): European Environment Agency; 2006.

[26] Rabou LPLM, Deurwaarder EP, Elbersen HW, Scott EL. Biomass in the Dutch energy infrastructure in 2030. Petten and Wageningen (Netherlands): ECN (Netherlands Energy Research Centre) and WUR (Wageningen University \& Research Centre); 2008 Jan.. p. 54.

[27] CBS. Population dynamics of the Netherlands [Internet]. Den Haag (Netherlands): Central Bureau of Statistics; 2011 Nov [cited 2012 Jan 8]. Available from: http://statline.cbs.nl/ StatWeb/publication/? $\mathrm{VW}=\mathrm{T} \& \mathrm{DM}=\mathrm{SLEN} \& \mathrm{PA}=37259$ eng\&LA $=\mathrm{EN}$.

[28] Holland Veepro. Forage management. Arnhem (Netherlands): Veepro Holland Information Centre for Dutch Cattle; 2011. p. 16.

[29] FAO. Forests and energy, key issues. FAO For Paper 2008;154(1):27-8.

[30] Scarlat N, Martinov M, Dallemand JF. Assessment of the availability of agricultural crop residues in the European Union: potential and limitations for bioenergy use. Waste Manage 2010;30(10):1889-97.

[31] Mulleneers E. Biogas production in agriculture and manure policy [Internet]. Den Bosch (Netherlands): Ministry of Economic Affairs, Agriculture and Innovation: International Seminar on Biogas; 2010 Nov 4. p. 13 [cited 2012 Jan 9]. Available from: http://www.iea-biogas.net/_download/ publications/workshop/9/Erik_Mulleneers_Agriculture_and_ Manure_Policy.pdf.

[32] Holm-Nielsen JB, Al Seadi T, Oleskowicz-Popiel P. The future of anaerobic digestion and biogas utilization. Bioresour Technol 2009;100(22):5478-84.

[33] DEFRA. The Biomass Environmental Assessment Tool (BEAT2), Worksheet - electricity and heat generated in a combined heat and power plant contained within a centralised anaerobic digestion plant using dairy manure as a feedstock [Internet]. London (United Kingdom): Department for Environment, Food and Rural Affairs (DEFRA); 2008 [cited 2011 Sep 26]. Available from: http:// www.biomassenergycentre.org.uk/portal/page?_pageid=74, 153193\&_dad=portal\&_schema=PORTAL.

[34] DEFRA. The Biomass Environmental Assessment Tool (BEAT2), Worksheet - electricity and heat generated in a combined heat and power plant contained within a centralised anaerobic digestion plant using pig manure as a feedstock [Internet]. London (United Kingdom): Department for Environment, Food and Rural Affairs (DEFRA); 2008 [cited 2011 Sep 26]. Available from: http://www.

biomassenergycentre.org.uk/portal/page?_pageid=74, 153193\&_dad=portal\&_schema=PORTAL.

[35] DEFRA. The Biomass Environmental Assessment Tool (BEAT2), Worksheet - electricity and heat generated in a combined heat and power plant contained within a centralised anaerobic digestion plant using wet poultry waste from egg-laying birds as a feedstock [Internet]. London (United Kingdom): Department for Environment, Food and Rural Affairs (DEFRA); 2008 [cited 2011 Sep 26]. Available from: http://www.biomassenergycentre.org.uk/portal/page? _pageid=74, 153193\&_dad=portal\&_schema=PORTAL.

[36] Bakker JP, Berendse F. Constraints in the restoration of ecological diversity in grassland and heathland communities. Trends Ecol Evol 1999;14(2):63-8.

[37] Oenema O, Velinga TV, van Keulen H. Nutrient management under grazing. In: Elgersma A, Dijkstra J, Tamminga S, editors. Fresh herbage for dairy cattle. Wageningen (Netherlands): Springer; 2006. p. 63-83.

[38] van Vuuren DP, Bellevrat E, Kitous A, Isaac M. Bio-energy use and low stabilization scenarios. Energy J 2010;31(1):193-221.

[39] NSCA. Biogas as a road transport fuel: an assessment of the potential role of biogas as a renewable transport fuel. Brighton (England, United Kingdom): National Society for Clean Air and Environmental Protection (NSCA); 2006. p. 52.

[40] Steffen R, Szolar O, Braun R. Feedstocks for anaerobic digestion. Vienna (Austria): Institute for Agrobiotechnology Tulln, University of Agricultural Sciences Vienna; 1998. p. 29.

[41] British Biogen. Good practice guidelines: anaerobic digestion of farm and food processing residues. London (England, United Kingdom): British Biogen; 2006. p. 52.

[42] Monnet F. An introduction to anaerobic digestion of organic wastes. Edinburgh (Scotland, United Kingdom): Remade Scotland; 2006. p. 57. Final report.

[43] EPA. Life cycle assessment: principles and practices. Reston (VA, USA): Scientific Applications International Corporation (SAIC); 2006 May. Report No.: EPA/600/R-06/060. Contract No.: 68-C02-067. Sponsored by EPA through its Office of Research and Development, Cincinnati (OH, USA).

[44] ORNL. Bioenergy conversion factors [Internet]. Oak Ridge National Laboratory, U.S Department of Energy; 2003 [cited 2011 Oct 10]. Available from: http://bioenergy.ornl.gov/ papers/misc/energy_conv.html.

[45] Meisterling K. On biomass appropriation: feeding animals and harvesting energy from organic matter [dissertation]. Pittsburgh (PA, United States): Carnegie Mellon Electricity Industry Center (CEIC), Department of Engineering and Public Policy, Carnegie Mellon University; 2011. p. 231.

[46] Gebrezgabher SA, Meuwissen MPM, Oude Lansink AGJM, Prins BAM. Economic analysis of anaerobic digestion - a case of green power biogas plant in the Netherlands. In: Proceedings of the 18th international farm management congress. Illinois, USA: Bloomington/Normal; 2009 July. p. $231-44$. 
[47] Downs HW, Hansen RW. Equipment: estimating farm fuel requirements. Fort Collins (CO, USA): Colorado State University Extension; 1996 Feb. p. 3 [rev. 1998 Sep]. Farm \& Ranch Series: Equipment 5(6).

[48] AEBIOM. A biogas road map for Europe. Brussels (Belgium): European Biomass Association; 2009. p. 24.

[49] Ozkan E, Harmon J. Estimating farm fuel requirements for crop production and livestock operations. Ames (IA, USA): Agricultural and Biosystems Engineering Department, Iowa State University; 1985 Mar [updated 1995 May].

[50] Uellendahl H, Wang G, Moller HB, Jorgensen U, Skiadas IV, Gavala HN, et al. Energy balance and cost-benefit analysis of biogas production from perennial energy crops pretreated by wet oxidation. Water Sci Technol 2008;58(9):1841-7.

[51] EUBIA. Anaerobic digestion [Internet]. Brussels (Belgium): European Biomass Industry Association (EUBIA); 2007 [cited 2011 Oct 20]. Available from: http://www.eubia.org/index. php/about-biomass/anaerobic-digestion.

[52] Porter JC, Seavey DC. Housing and space guidelines for livestock. Manchester (NH, USA): University of New Hampshire Cooperative Extension; 2009 Jun. p. 3.

[53] Grzywiński W. Energy load of workers employed at timber harvesting. Elect J Polish Agric Universities (EJPAU) 2004;7(2)

[54] Arodudu OT, Voinov A, van Duren I. BE 2.0 project \& NEGEROEI calculator [internet]. Enschede (Netherlands): Sustainable BioEnergy; 2012 [cited 2012 Dec 12]. Available from: http://www.likbez.com/BE/.

[55] Fehrs JE. Vermont methane pilot project resource assessment. Montpelier (Vermont, United States): Vermont Department of Public Service and Vermont Department of Agriculture, Food and Markets; 2000 Jul. p. 56.

[56] Oosterbaan A, de Jong JJ, Kuiters AT. Vernieuwing in ontwikkeling en beheer van natuurgraslanden op voormalige landbouwgrond op droge zandgronden [Innovation in development and management of natural meadows on fallow lands under dry sandy soil conditions]. Wageningen (Netherlands): Wageningen Alterra; 2008. p. 58. Alterrarapport 1669. [in Dutch].

[57] Rösch C, Skarka J, Raab K, Stelzer V. Energy production from grassland - assessing the sustainability of different process chains under German conditions. Biomass Bioenergy 2009;33(4):689-700.

[58] Wiktorsson H, Spörndly E. Grazing: an animal welfare issue for automatic milking farms. In: Proceedings of the first
North American conference on robotic milking, 2002 Mar 20-22; Toronto, Canada. Wageningen (Netherlands): Wageningen Academic Publishers; 2002VI32-43.

[59] Spörndly E, Wredle E. Automatic milking and grazing-effects of location of drinking water on water intake, milk yield, and cow behavior. J Dairy Sci 2005;88(5):1711-22.

[60] Guilford MC, Hall CAS, O'Connor P, Cleveland CJ. A new long term assessment of energy return on investment (EROI) for U.S. oil and gas discovery and production. Sustainability 2011;3(10):1866-87.

[61] Bull J. EROEI of electricity generation. Powys (Wales, United Kingdom): Offshore Valuation Group, Public Interest Research Centre (PRIC); 2010.

[62] Koop K, Koper M, Bijsma R, Wonink S, Ouwens, JD. Final report: evaluation of improvements in end-conversion efficiency for bioenergy production. Brussels (Belgium): Ecofys; 135 p.

[63] FortisBC. Material safety data sheet - natural gas (pipeline quality - MSDS \#526). Vancouver (British Columbia, Canada): FortisBC; 2009 July 10. p. 5 [rev. 2012 Jan 26].

[64] EPA. EPA coalbed methane outreach program technical options series: upgrading medium quality coal mine gas by blending and spiking [Internet]. Washington (U.S): Coalbed Methane Outreach Program U.S. EPA; 1998. p. 5.

[65] Cavanagh A, Gasser MO, Labrecque M. Pig slurry as fertilizer on willow plantation. Biomass Bioenergy 2011;35(10):4165-73.

[66] Brock EH, Ketterings QM, McBride M. Copper and zinc accumulation in poultry and dairy manure-amended fields. Soil Sci 2006;171(5):388-99.

[67] Ibrahim ES. Biomass potentials for bioenergy production from build-up areas [dissertation]. Enschede (Netherlands): Faculty of Geoinformation Science and Earth Observation (ITC), University of Twente; 2012. p. 68.

[68] Gell K. Review of small scale, community biogas in the industrialized world. Wageningen (Netherlands): Community Composting Network (CCN), Wageningen University, Netherlands; 2008 Aug. p. 20.

[69] Arodudu OT, Voinov A, van Duren I. Assessing bioenergy potentials in rural landscapes. In: IAIA12 conference proceedings, 32nd annual meeting of the international association for impact assessment: energy future - the role of impact assessment. 2012 may 27-Jun 1. Porto, Portugal: Centro de Congresso da Alfândega; 2012. p. 6. 